\title{
Impact of Biofield Treatment on Atomic and Structural Characteristics of Barium Titanate Powder
}

\author{
Trivedi MK'1, Nayak G'1, Patil S', Tallapragada RM'1, Latiyal $\mathbf{O}^{2}$ and Jana $\mathbf{S}^{2 *}$ \\ ${ }^{1}$ Trivedi Global Inc., 10624 S Eastern Avenue Suite A-969, Henderson, NV 89052, USA \\ ${ }^{2}$ Trivedi Science Research Laboratory Pvt. Ltd., Hall-A, Chinar Mega Mall, Chinar Fortune City, Hoshangabad Rd., Bhopal- 462026 Madhya Pradesh, India
}

\begin{abstract}
Barium titanate, perovskite structure is known for its high dielectric constant and piezoelectric properties, which makes it interesting material for fabricating capacitors, transducer, actuator, and sensors. The perovskite crystal structure and lattice vibrations play a crucial role in its piezoelectric and ferroelectric behavior. In the present study, the barium titanate powder was subjected to biofield treatment. Further, the control and treated samples were characterized using X-ray diffraction (XRD) and Fourier transform infrared spectrometer (FT-IR) and Electron spin resonance (ESR). The XRD analysis showed the permanent compressive strain of $0.45 \%$ in treated barium titanate powder as compared to control. Furthermore, the biofield treatment has enhanced the density upto $1.38 \%$ in barium titanate as compared to control. The FT-IR spectra showed that the stretching and bending vibrations of Ti-O bond in treated $\mathrm{BaTiO}_{3}$ were shifted towards lower frequency as compared to control. The bond length was substantially increased by $0.72 \%$ in treated $\mathrm{BaTiO}_{3}$ as compared to control. The ESR spectra of control and treated $\mathrm{BaTiO}_{3}$ sample showed the g-factor of 2.0; and biofield treatment has substantially changed the width and height of ESR signal in treated $\mathrm{BaTiO}_{3}$ as compared to control. These observations revealed that biofield treatment has significantly altered the crystal structure, lattice strain, and bond vibration of barium titanate.
\end{abstract}

Keywords: Biofield treatment; Barium titanate; Fourier transform infrared; X-Ray diffraction; Electron spin resonance

\section{Introduction}

Piezoelectric materials are commonly used in optoelectronic industries in fabricating sensor, capacitor, and actuator owing to their piezoelectricity and wide range of dielectric constant. In these materials a strong relationship exists between mechanical displacements and electric field i.e. it induce electric polarization in response to applied stress and strained in response to applied electric fields. The perovskite structure, $\mathrm{ABO}_{3}$ type material usually exhibits spontaneous polarizations in response to mechanical stress [1]. Additionally, this perovskite structure is promising in positive coefficient (PCT) resistors, light-emission devices, and field emission displays (FEDs) [2]. The perovskite, barium titanate $\left(\mathrm{BaTiO}_{3}\right)$ has recently gain significant attention due to its demand for lead-free piezoelectric materials in several industries. In addition to that, the perovskite structure of $\mathrm{BaTiO}_{3}$ attracted significant attention due to its exceptional dielectric, piezoelectric, and electro optic properties [3]. These exceptional properties make it a promising material for other applications such as multilayer ceramic capacitors (MLCCs), dynamic random access ferroelectric memories (DRAMs) [4]. This material requires non-centrosymmetric crystal structure to behave as piezoelectric, because its centrosymmetric cubic crystal structure doesn't show piezoelectricity, whereas hexagonal, tetragonal, orthorhombic, and rhombohedral shows due to their non-centrosymmetric structure [1]. In $\mathrm{BaTiO}_{3}$ the piezoelectricity is highly depends upon its crystal structure, lattice vibration, and grain size etc. Furthermore, in order to alter its piezoelectric and ferroelectric properties, many researchers have used various doping methods to modify the dielectric and piezoelectric properties $[5,6]$. Recently, it was reported that distortion in perovskite $\mathrm{BatiO}_{3}$ reduced symmetry, which enhanced its magnetic and electrical properties [7]. Moreover, Chernova et al. demonstrated that strain induced in $\mathrm{BaTiO}_{3}$ unit cell enhanced its ferroelectric polarizations [8]. Thus, after considering the vast importance of $\mathrm{BatiO}_{3}$ and its crystal structure in several applications, authors wish to investigate an approach that could be beneficial to modify the atomic and structural properties of $\mathrm{BatiO}_{3}$ powder.

William Tiller, a physicist, reported that the existence of a new force related to human body, in addition to four well known fundamental forces of physics such as gravitational force, strong force, weak force, and electromagnetic force [9]. Biophysicist Fritz-Albert Popp et al. reported that human physiology shows a high degree of order and stability due to their coherent dynamic states [10-13]. This coherent dynamic state of human body emits the electromagnetic waves in form of bio-photons, which surrounds the body and it is known as biofield. Therefore, the biofield consisting of electromagnetic field, generated by moving electrically charged particles (ions, cell, molecule etc.) inside the human body. Furthermore, a human has ability to harness the energy from environment/universe and can transmit into any object (living or non-living) around the Globe. The object(s) always receive the energy and responded into useful way that is called biofield energy. This process is termed as biofield treatment. Mr. Trivedi's unique biofield treatment is known as The Trivedi effect ${ }^{\mathbb{B}}$. Mr. Trivedi's biofield treatment is known to alter the crystal structure and atomic level changes in various ceramics and metals [14-21]. Additionally, the biofield treatment has also transformed the molecular and cellular properties in agriculture [22-24], microbiology [25-27] and biotechnology [28,29]. Recently, it was reported that biofield treatment had increased the particle size by six fold and enhanced the crystallite size by two fold in zinc powder [14]. In another report,

*Corresponding author: Snehasis Jana, Trivedi Science Research Laboratory Pvt. Ltd., Hall-A, Chinar Mega Mall, Chinar Fortune City, Hoshangabad Rd., Bhopal- 462026, Madhya Pradesh, India, Tel: +91-755-6660006; E-mail: publication@trivedisrl.com

Received June 22, 2015; Accepted August 04, 2015; Published August 06, 2015

Citation: Trivedi MK, Nayak G, Patil S, Tallapragada RM, Latiyal O, et al. (2015) Impact of Biofield Treatment on Atomic and Structural Characteristics of Barium Titanate Powder. Ind Eng Manage 4: 166. doi:10.4172/2169-0316.1000166

Copyright: ( $) 2015$ Trivedi MK, et al. This is an open-access article distributed under the terms of the Creative Commons Attribution License, which permits unrestricted use, distribution, and reproduction in any medium, provided the original author and source are credited. 
Citation: Trivedi MK, Nayak G, Patil S, Tallapragada RM, Latiyal O, et al. (2015) Impact of Biofield Treatment on Atomic and Structural Characteristics of Barium Titanate Powder. Ind Eng Manage 4: 166. doi:10.4172/2169-0316.1000166

biofield treatment has shown the significant effect in carbon allotropes, where the unit cell volume was decrease by $1 \%$ and crystallite size was increased by $100 \%$ [15]. To the best of our knowledge, this is the first report to evaluate the impact of biofield treatment on atomic and structural characteristics of $\mathrm{BaTiO}_{3}$ powder.

\section{Materials and Methods}

$\mathrm{BaTiO}_{3}$ powder was procured from the Sigma-Aldrich (MA, USA). The powder sample was divided into two equal groups i.e. control and treatment. The control group was remained as untreated and treatment group was subjected to biofield treatment.

\section{Biofield treatment}

The treatment group was handed over in sealed pack to Mr. Trivedi for biofield treatment under standard laboratory condition. Mr. Trivedi provided this treatment through his energy transmission process to the treatment group without touching the samples. After that, both control and treated samples were characterized using X-ray diffraction (XRD), Fourier-transform infrared spectrometer (FT-IR) and Electron spin resonance (ESR).

\section{$X$-ray diffraction study}

For XRD analysis, treated sample was further divided into two parts as T1 and T2. XRD analysis was carried out using a Phillips, Holland PW 1710 XRD system, which had a copper cathode with nickel filter. The wavelength of X-ray radiation used was $1.54056 \AA$. The data obtained from the XRD was in the form of chart of intensity vs. $2 \theta^{\circ}$ with a detailed table containing d value $(\AA)$, number of peaks, peak width $2 \theta^{\circ}$, peak count, and relative intensity of peaks, etc. The lattice parameter and unit cell volume were computed using Powder $\mathrm{X}$ software. The molecular weight was calculated as the sum of atomic weight of all the atoms present in a molecule. The atomic weight was calculated as the sum of the weight of all protons, neutrons and electrons present in the atom. The weight of the unit cell was calculated as: atomic weight multiplied by the number of atoms present in a unit cell. The density of the unit cell was computed as ratio of unit cell weight to unit cell volume. The percentage change in the unit cell volume was calculated using the following equation:

\section{$\%$ change in unit cell volume: $(\Delta \mathrm{V} / \mathrm{Vc}) \times 100$.}

Here, $\Delta \mathrm{V}=(\mathrm{Vt}-\mathrm{Vc}) / \mathrm{Vc}$ where $\mathrm{Vt}$ and $\mathrm{Vc}$ are the unit cell volume of treated and control samples, respectively. The percent change in all other parameters such as density, molecular weight, and lattice parameter were calculated in the similar way.

\section{Fourier transform infrared spectroscopy}

Both, control and treated $\mathrm{BaTiO}_{3}$ were characterized using Shimadzu, Fourier transform infrared (FT-IR) spectrometer with frequency range of $300-4000 / \mathrm{cm}$.

\section{Electron spin resonance spectroscopy}

ESR analysis of control and treated $\mathrm{BaTiO}_{3}$ samples were carried out on E-112 ESR spectrometer of Varian USA of X-band microwave frequency $(9.5 \mathrm{GHz})$, which had sensitivity of $5 \times 10^{10}, \Delta \mathrm{H}$ spins was used to analyze the electron spin properties.

\section{Results and Discussion}

\section{$\mathrm{X}$-ray diffraction study}

XRD pattern of control and treated $\mathrm{BaTiO}_{3}$ are shown in Figure
1. The peaks were observed at $2 \theta=22.0^{\circ}, 31.3^{\circ}, 38.70^{\circ}, 45.11^{\circ}, 50.72^{\circ}$, $55.97^{\circ}$, and $65.8^{\circ}$ in control Figure 1a, which indexed for tetragonal crystal structure of $\mathrm{BaTiO} 3$ as per Joint Committee on Powder Diffraction Standards (JCPDS) 05-0626. Furthermore, diffraction peaks were observed at $2 \theta=22.13^{\circ}, 23.9^{\circ}, 31.5^{\circ}, 38.9^{\circ}, 45.2^{\circ}, 50.8^{\circ}, 56.1^{\circ}$ and $65.8^{\circ}$ in $\mathrm{T} 1$ (Figure $1 \mathrm{~b}$ ), and $22.0^{\circ}, 23.9^{\circ}, 31.5^{\circ}, 38.8^{\circ}, 45.2^{\circ}, 50.9^{\circ}$, $56.2^{\circ}, 65.8^{\circ}$ in T2 (Figure 1c). In addition, lattice parameter and unit cell volume of control and treated samples were computed using Powder $\mathrm{X}$ software and result are presented in Table 1. It was found that the

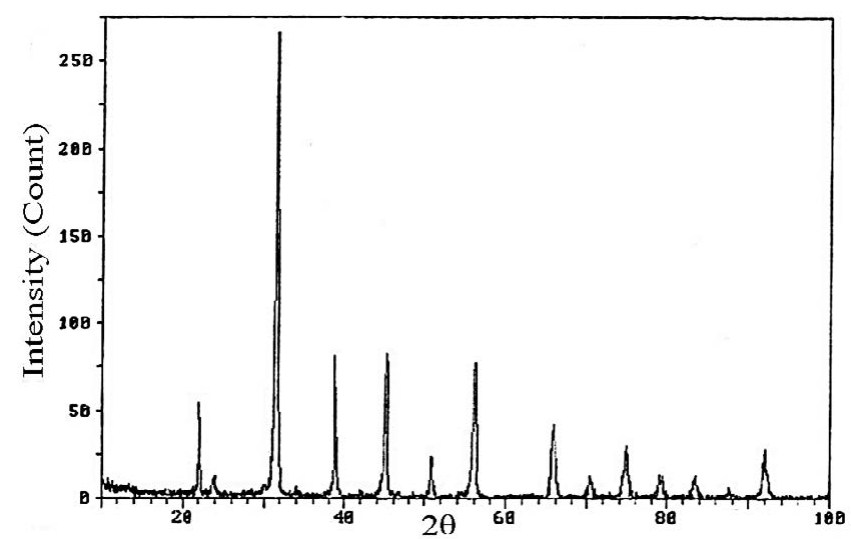

Figure 1a: XRD pattern of control barium titanate powder.

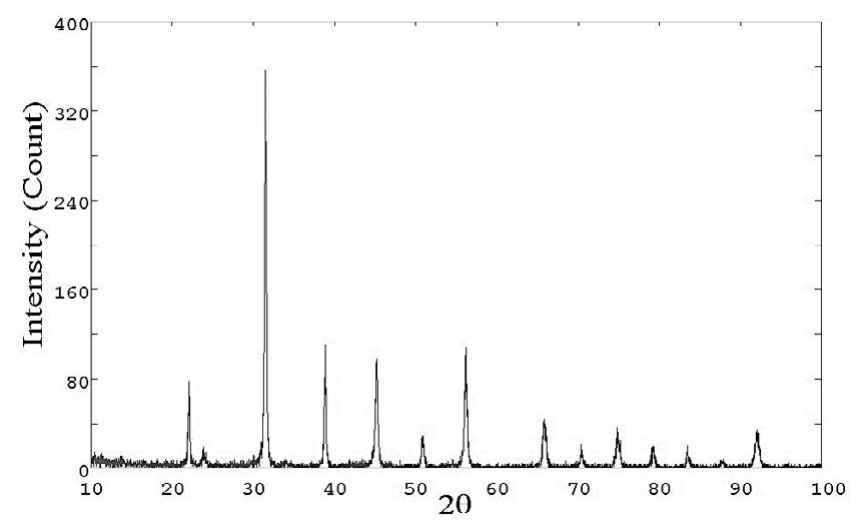

Figure 1b: XRD pattern of biofield treated barium titanate powder sample (T1)

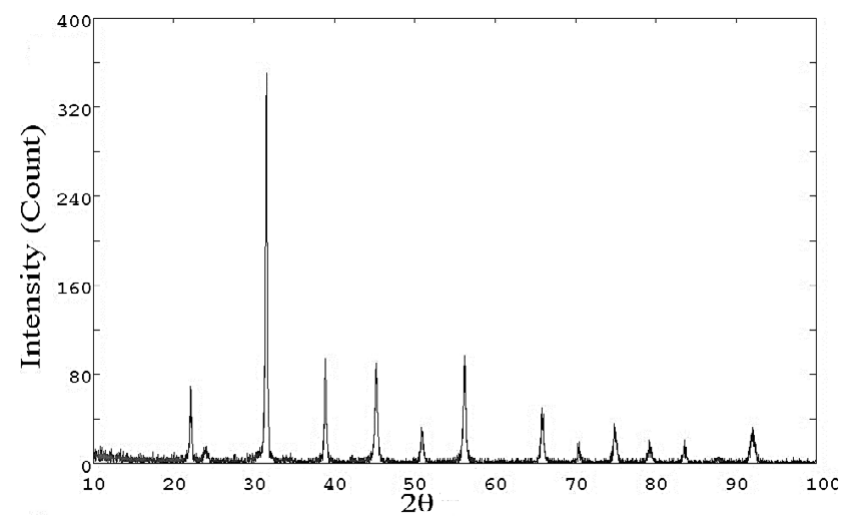

Figure 1c: XRD pattern of biofield treated barium titanate powder sample (T2). 
Citation: Trivedi MK, Nayak G, Patil S, Tallapragada RM, Latiyal O, et al. (2015) Impact of Biofield Treatment on Atomic and Structural Characteristics of Barium Titanate Powder. Ind Eng Manage 4: 166. doi:10.4172/2169-0316.1000166

Page 3 of 6

\begin{tabular}{|c|c|c|c|c|c|c|c|c|}
\hline & Lattice parameter $(\mathbf{A})$ & $\%$ change & Unit cell volume $\left(\mathrm{cm}^{3}\right)$ & $\%$ change & Density (g/cc) & $\%$ change & Mol. Wt. (g/Mol) & $\%$ change \\
\hline Control & 4.030 & & $6.55 \times 10^{-23}$ & & 5.954 & & 235.01 & \\
\hline Treated T1 & 4.010 & -0.45 & $6.46 \times 10^{-23}$ & -1.36 & 6.036 & 1.38 & 231.82 & -1.36 \\
\hline Treated T2 & 4.015 & -0.43 & $6.47 \times 10^{-23}$ & -1.29 & 6.032 & 1.30 & 231.98 & -1.29 \\
\hline
\end{tabular}

Table 1: X-ray diffraction analysis result of barium titanate powder.

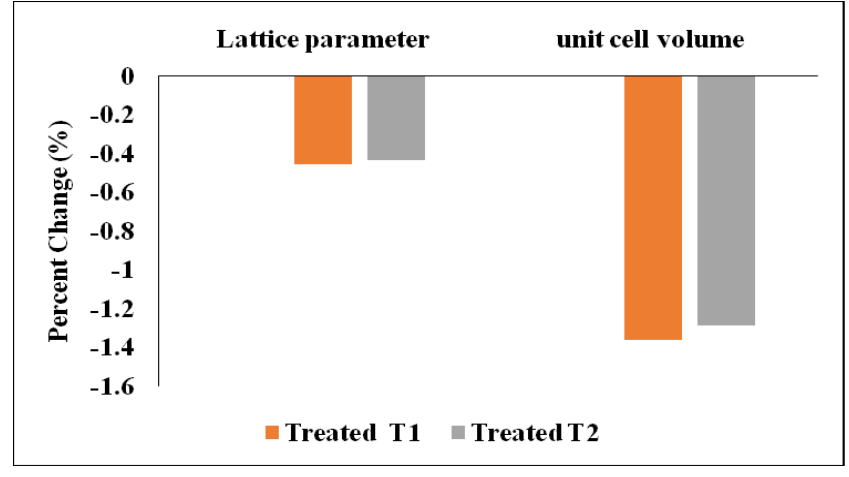

Figure 2: Effect of biofield treatment on the lattice parameter and unit cell volume of barium titanate powder.

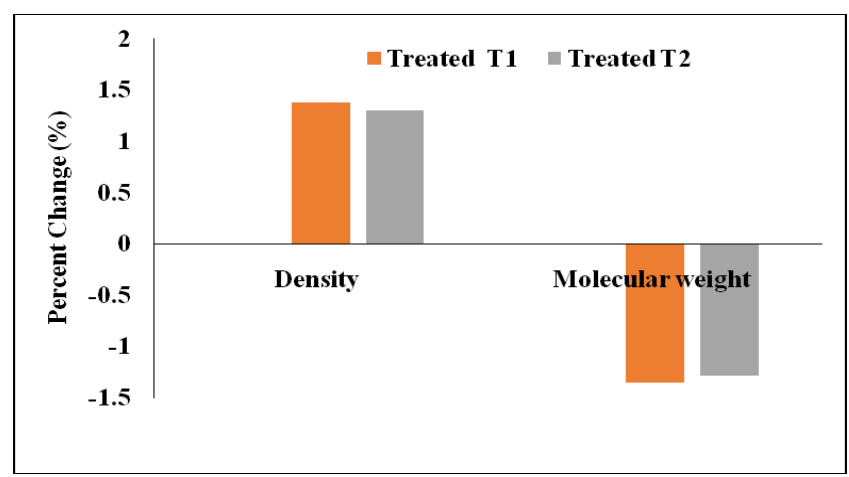

Figure 3: Effect of biofield treatment of density and molecular weight of barium titanate powder.

lattice parameter of the unit cell was reduced from $4.03 \AA$ (control) to $4.01 \AA$ (treated) after biofield treatment that resulted into negative lattice strain of $0.45 \%$ in $\mathrm{BaTiO}_{3}$ unit cell. Further, this compressive strain led to reduce the volume of the unit cell upto 1.36 and $1.29 \%$ in treated samples $\mathrm{T} 1$ and $\mathrm{T} 2$, respectively (Figure 2). This reduced unit cell volume caused an increase in density by 1.38 and $1.30 \%$ in treated $\mathrm{T} 1$ and T2, respectively as compared to control (Figure 3). It is well known that $\mathrm{BaTiO}_{3}$ shows piezoelectric and converse piezoelectric effect [1]. In converse piezoelectric effect, the $\mathrm{BaTiO}_{3}$ unit cell responds to applied electric field that results into mechanical strain. Besides this, the unit cell parameter of $\mathrm{BaTiO}_{3}$ was strained upto $-0.45 \%$ that might be due to electric field required by converse piezoelectric behavior of $\mathrm{BaTiO}_{3}$. It is hypothesized that the induced strain in treated sample may be due to electric field supplied through biofield treatment. Further, when electric field supplied through biofield treatment the negative ions $\left(\mathrm{O}^{2-}\right)$ tend to move toward the positive electric field whereas the positive ions $\left(\mathrm{Ti}^{+4}\right)$ moved toward negative side. Due to movement of these ions toward each other, this compressive strain may be induced in $\mathrm{BaTiO}_{3}$ unit cell. However, when electric field supply turned off in piezoelectric materials, the unit cell comes back

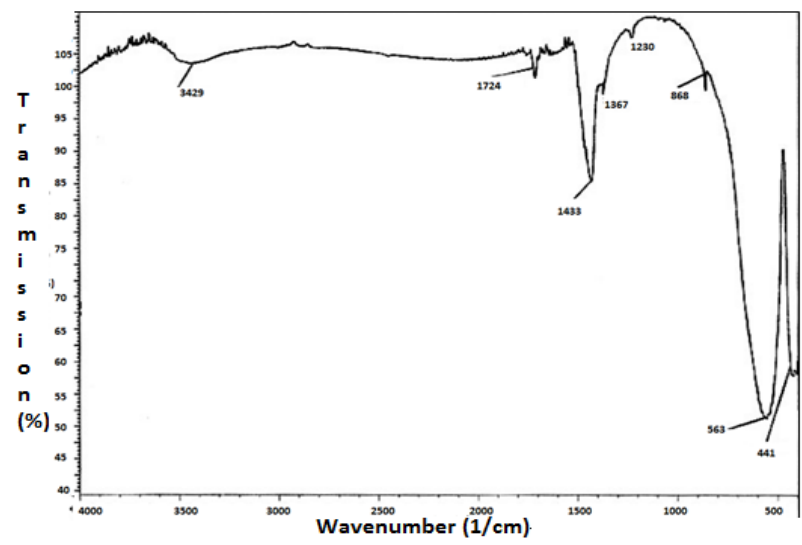

Figure 4: FT-IR spectrum of controlbarium titanate sample.

to its original shape and become unstrained [30]. On the contrary, in this experiment the lattice strain was permanent, i.e. the unit cell was permanently distorted after biofield treatment. Thus, it is postulated that biofield treatment acting at atomic level to induce this permanent strain in $\mathrm{BaTiO}_{3}$. Additionally, it was also observed that the molecular weight was reduced upto $1.36 \%$ after the treatment, which indicates that the biofield treatment possibly acting at nuclear level to cause these changes. Furthermore, Y. Tanaka et al. demonstrated that compressive strain in $\mathrm{BaTiO}_{3}$ increased the remnant polarization and reduced the dielectric permittivity that enhanced the piezoelectric coefficient [31]. In addition to that, this compressive strain found in treated $\mathrm{BaTiO}_{3}$ may lead to reduce the symmetry of the crystal structure. The reduction in symmetry probably enhanced the piezoelectric properties in treated $\mathrm{BaTiO}_{3}$ as compared to control $[8,9]$.

\section{Fourier transform infrared spectroscopy}

FT-IR of $\mathrm{BaTiO}_{3}$ control and treated samples are presented in Figure 4 and 5, respectively. FT-IR spectra displayed two strong absorption peaks at $441 / \mathrm{cm}$ and $563 / \mathrm{cm}$ in control (Figure 4); and $430 /$ $\mathrm{cm}$ and $557 / \mathrm{cm}$ in treated samples (Figure 5). The former peaks (441/ $\mathrm{cm}$ and $430 / \mathrm{cm}$ ) were assigned to Ti-O bending vibrations along the polar axis whereas the latter peaks $(563 / \mathrm{cm}$ and $557 / \mathrm{cm})$ were assigned to Ti-O stretching vibrations as shown in Figure 6. These peaks suggest that both treated and control sample had pure tetragonal phase [32]. The comparative result analysis of Ti-O bond vibrations is presented in Table 2 and Figure 7. It was observed that the absorption peak frequency of Ti-O bond stretching and bending vibrations were shifted toward lower frequency by 1.06 and $2.49 \%$ respectively in treated $\mathrm{BaTiO}_{3}$ as compared to control sample (Figure 7). Further, the peaks at $868 / \mathrm{cm}$ in control and treated were assigned to stretching vibrations of metal-oxygen. The peaks displayed at 1724 and $3429 / \mathrm{cm}$, in control and treated samples were attributed to moisture absorption by samples. Additionally, the bond force constant $(\mathrm{k})$ and bond length for Ti-O bond were calculated using following equations [33]: 
Citation: Trivedi MK, Nayak G, Patil S, Tallapragada RM, Latiyal O, et al. (2015) Impact of Biofield Treatment on Atomic and Structural Characteristics of Barium Titanate Powder. Ind Eng Manage 4: 166. doi:10.4172/2169-0316.1000166

Page 4 of 6

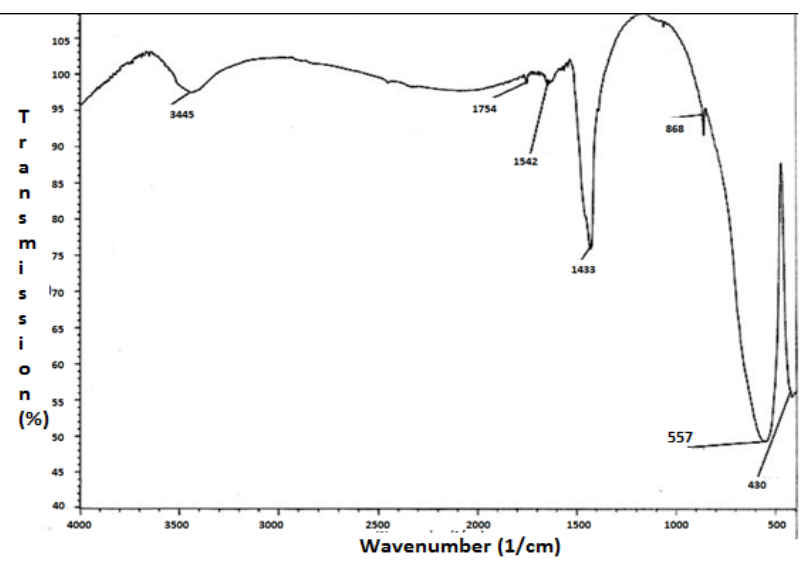

Figure 5: FT-IR spectrum of biofield treated barium titanate powder.

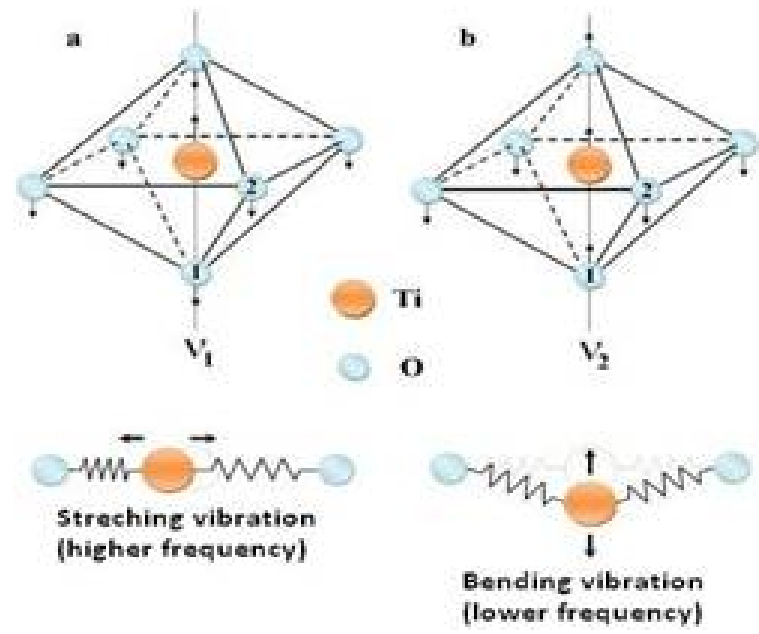

Figure 6: Strecthing and bending vibrations of Ti-Obonds in $\mathrm{BaTiO}_{3}$.

\begin{tabular}{|c|c|c|}
\hline & \multicolumn{2}{|c|}{ IR Absorption Peaks $\mathbf{( c m}^{-1}$ ) } \\
\hline & Stretching Vibration (Ti-O) & Bending Vibration (Ti-O) \\
\hline Control & 563 & 441 \\
\hline Treated & 557 & 430 \\
\hline
\end{tabular}

Table 2: FT-IR Strecthing and bending vibration frequency of Ti-O bond in barium titanate powder.

$$
v=\frac{1}{2 \pi \mathrm{c}} \sqrt{\frac{k}{\mu}}
$$

Where, $c=$ speed of light $(\mathrm{cm} / \mathrm{s}), \mu=$ effective mass of Titanium and oxygen, which can be calculated as given below

$$
\mu=\frac{\left(M_{T i} \times M_{O}\right)}{\left(M_{T i}+M_{O}\right)}
$$

Where, $\mathrm{M}_{\mathrm{Ti}}=$ Atomic mass of titanium $(\mathrm{Kg}), \mathrm{M}_{\mathrm{O}}=$ Atomic mass of oxygen $(\mathrm{Kg}), v=\mathrm{IR}$ wavenumber $(/ \mathrm{cm})$.

The bond force constant $(\mathrm{k})$ is related to average bond length $(\mathrm{r})$ by following equation [34]:

$$
\mathrm{k}=17 / \mathrm{r} 3
$$

The bond length and force constant were calculated using equations (1) and (3), respectively, which are illustrated in Figure 8. Data showed that bond force constant was reduced from $2.24 \mathrm{~N} / \mathrm{cm}$ (control) to $2.19 \mathrm{~N} / \mathrm{cm}$ (treated) after biofield treatment. It suggest that bond force constant of Ti-O was significantly decreased by $2.12 \%$ in treated $\mathrm{BaTiO}_{3}$ as compared to control (Figure 9). Furthermore, bond length of Ti-O

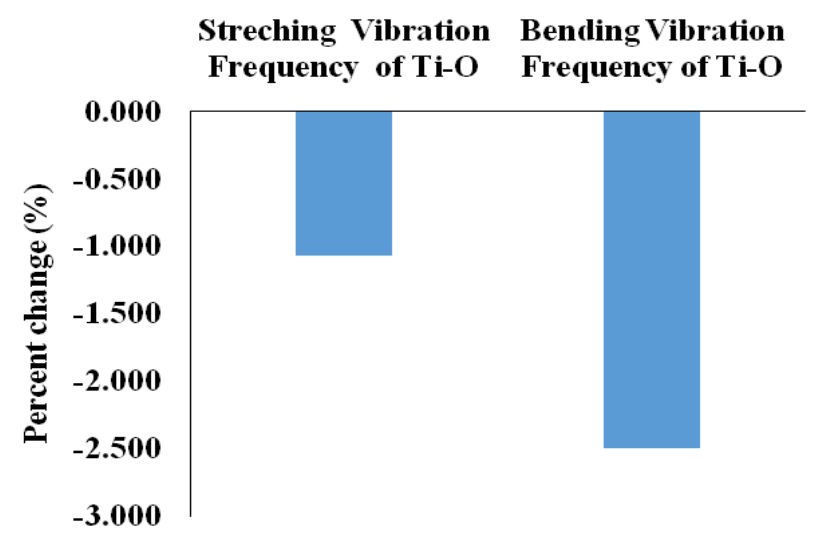

Figure 7: Effect of biofield treatment on the strecthing and bending vibration frequency of Ti-O bond of barium titanate powder.

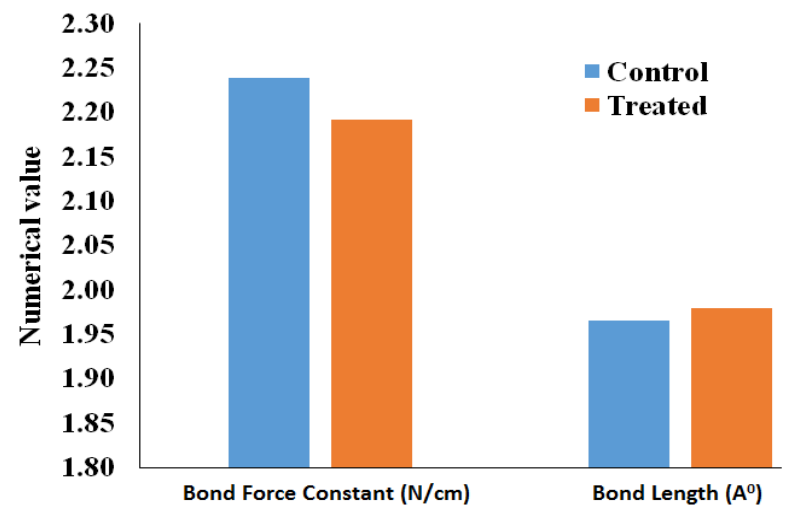

Figure 8: Bond force constant and bond length result of Ti-O bond in control and biofield treated barium titanate powder.

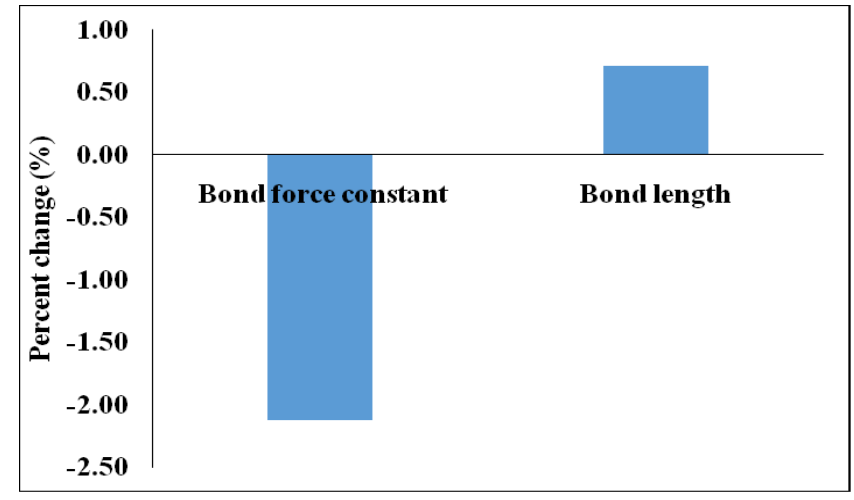

Figure 9: Effect of biofield treatment on bond force constant and bond length of Ti-O in barium titanate powder. 
Citation: Trivedi MK, Nayak G, Patil S, Tallapragada RM, Latiyal O, et al. (2015) Impact of Biofield Treatment on Atomic and Structural Characteristics of Barium Titanate Powder. Ind Eng Manage 4: 166. doi:10.4172/2169-0316.1000166

Page 5 of 6

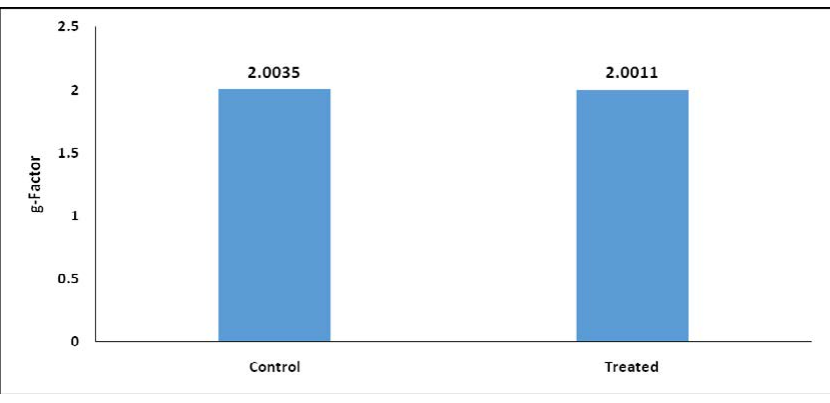

Figure 10: Effect of biofield treatment on g-factor of barium titanate powder.

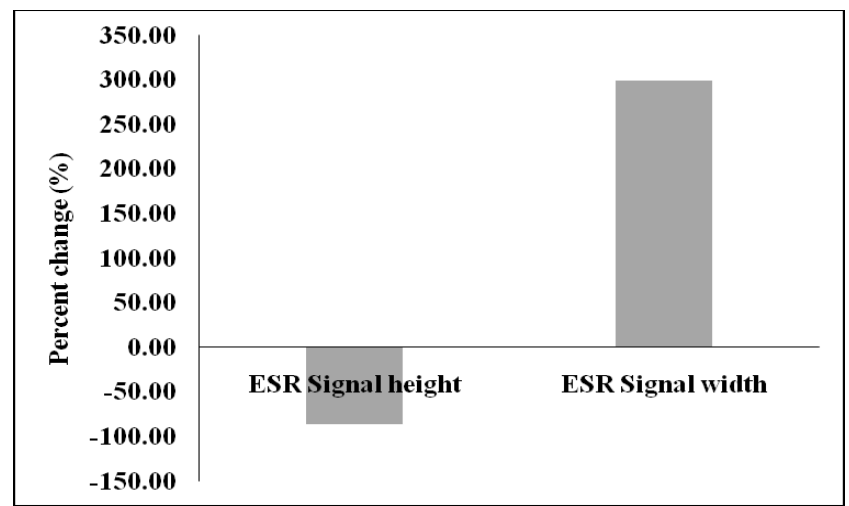

Figure 11: Effect of biofield treatment of ESR signal height and width of barium titanate powder.

was increased in treated $(1.979 \AA)$ as compared to control $(1.965 \AA)$. This indicates that the Ti-O bond length was increased by $0.72 \%$ after biofield treatment (Figure 9). Additionally, the shifting of bending vibrational frequency from $441 / \mathrm{cm}$ (control) to $430 / \mathrm{cm}$ (treated) might be due to distortion of $\mathrm{BaTiO}_{3}$ unit cell after biofield treatment [35]. These findings suggest that biofield treatment has significantly altered the bond properties and vibrations of crystal lattice possibly through the electric and magnetic fields. Sun et al. demonstrated that the vibrations of crystal lattice of $\mathrm{BaTiO}_{3}$ had significant effect on its Ferro-electricity and piezoelectricity [35].

\section{Electron spin resonance spectroscopy}

The ESR spectroscopic data are presented in Figure 10 and 11.The g-factors computed from ESR spectra were 2.0035 and 2.0011 for control and treated $\mathrm{BaTiO}_{3}$, respectively (Figure 10). The signal for g-factor at 2.00035 and 2.0011 were probably originated due to titanium vacancy with unpaired electron spin [36]. It was also observed that ESR signal height was reduced by $85.71 \%$; and width was increased by $300 \%$ as compared to control (Figure 11 ). The decrease in intensity and broadening of ESR signal implies that the particle size probably reduced after treatment [37]. It is postulated that during biofield treatment, the energy has been transferred to $\mathrm{BaTiO}_{3}$ powder sample in form of electric and magnetic field, which may induced high energy milling and resulted into smaller particle size.

\section{Conclusion}

In summary, the biofield treatment has induced the permanent compressive lattice strain in tetragonal crystal structure of $\mathrm{BaTiO}_{3}$, which may occur due to electromagnetic field transferred through biofield treatment. This permanently strained crystal structure of $\mathrm{BaTiO}_{3}$ led to alter its piezoelectric behavior. The FT-IR analysis result revealed that $\mathrm{Ti}-\mathrm{O}$ bond length in $\mathrm{BaTiO}_{3}$ was increased by $0.72 \%$ after biofield treatment as compared to control. Therefore, these findings indicate that biofield treatment may be acting at atomic level of $\mathrm{BaTiO}$ to cause these modifications. Furthermore, the variation observed in width and height of ESR spectra, which suggest that particle size of treated $\mathrm{BaTiO}_{3}$ might be altered through high energy milling process. Hence, it is hypothesized that biofield treatment has induced the electric and magnetic field that can affect the $\mathrm{BaTiO}_{3}$ powder at electronic and atomic level. To conclude, the biofield treatment could be applied to alter the crystal structure and piezoelectricity of $\mathrm{BaTiO}_{3}$ powder.

\section{Acknowledgment}

Authors gratefully acknowledged to Dr. Cheng Dong of NLSC, Institute of Physics, and Chinese academy of Sciences for providing the facilities to use PowderX software for analyzing XRD data. Authors also would like to thank Trivedi Science, Trivedi master wellness and Trivedi testimonials for their support during the work.

\section{References}

1. Aksel E, Jones JL (2010) Advances in lead-free piezoelectric materials for sensors and actuators. Sensors 10: 1935-1954.

2. García-Hernández M, García-Murillo A, Carrillo-Romo FDJ, Jaramillo-Vigueras $\mathrm{D}$, Chadeyron $\mathrm{G}$ (2009) Eu-doped $\mathrm{BaTiO}_{3}$ powder and film from sol-gel process with polyvinylpyrrolidone additive. Int J Mol Sci 10: 4088-4101.

3. Hao S, Fu D, Li J, Wang W, Shen B (2011) Preparation and characterization of Ag-Doped $\mathrm{BaTiO}_{3}$ conductive powder. Int J Inorg Chem 2011: 1-4.

4. Bhuiyan MRA, Alam MM, Momin MA, Uddin MJ, Islam M (2012) Synthesis and characterization of barium titanate $\left(\mathrm{BaTiO}_{3}\right)$ nanoparticle. Int $\mathrm{J}$ Mater and Mech Eng 1: 21-24.

5. Vijatovića MM, Stojanovića BD, Bobića JD, Ramoskab T, Bowenc P (2010) Properties of lanthanum doped $\mathrm{BaTiO}_{3}$ produced from nanopowders. Ceram Int 36(6): 1817-1824.

6. Slipenyuk AM, Glinchuk MD, Bykov IP, Yurchenko LP, Mikheev VA et al. (2003) Study of $\mathrm{BaTiO} 3$ ceramics doped with $\mathrm{Mn}$ and $\mathrm{Ce}$ or $\mathrm{Nb}$ and $\mathrm{Sr}$. Condens Matter Phys 6: 237-244.

7. Pradhan S, Roy GS (2013) Study the crystal structure and phase transition of $\mathrm{BaTiO}_{3}-\mathrm{A}$ pervoskite. Researcher 5: 63-67.

8. Chernova E, Pacherova O, Chvostova D, Dejneka A, Kocourek T et al. (2015) Strain-controlled optical absorption in epitaxial ferroelectric $\mathrm{BaTiO}_{3}$ films. Appl Phys Lett 106: 192903.

9. Tiller WA (1997) Science and human transformation: subtle energies, intentionality and consciousness (1stedn). Pavior Publishing, Walnut Creek California.

10. Popp FA, Li K, Gu Q (1992). Recent advances in biophoton research and its application. World Scientific Publishing Co. Pvt. Ltd.

11. Popp FA, Quao G, Ke-Hsuen L (1994) Biophoton emission: experimental background and theoretical approaches. Mod Phys Lett B 8: 21-22.

12. Popp FA, Chang JJ, Herzog A, Yan Z, Yan Y (2002) Evidence of non-classical (squeezed) light in biological systems. Phys Lett 293: 98-102.

13. Cohen S, Popp FA (2003) Biophoton emission of the human body. Indian J ExpBiol 41: 440-445.

14. Trivedi MK, Tallapragada RM (2008) A transcendental to changing metal powder characteristics. Met Powder Rep 63: 22-28, 31.

15. Trivedi MK, Tallapragada RM (2009) Effect of super consciousness external energy on atomic, crystalline and powder characteristics of carbon allotrope powders. Mater Res Innov 13: 473-480.

16. Dhabade VV, Tallapragada RM, Trivedi MK (2009) Effect of external energy on atomic, crystalline and powder characteristics of antimony and bismuth powders. Bull Mater Sci 32: 471-479. 
Citation: Trivedi MK, Nayak G, Patil S, Tallapragada RM, Latiyal O, et al. (2015) Impact of Biofield Treatment on Atomic and Structural Characteristics of Barium Titanate Powder. Ind Eng Manage 4: 166. doi:10.4172/2169-0316.1000166

17. Trivedi MK, Patil S, Tallapragada RM (2012) Thought Intervention through bio field changing metal powder characteristics experiments on powder characteristics at a PM plant. Future Control and Automation LNEE 173: 247-252.

18. Trivedi MK, Patil S, Tallapragada RM (2013) Effect of biofield treatment on the physical and thermal characteristics of silicon, tin and lead powders. J Material Sci Eng 2: 125.

19. Trivedi MK, Patil S, Tallapragada RM (2013) Effect of biofield treatment on the physical and thermal characteristics of Vanadium Pentoxide powder. J Material Sci Eng S11: 001.

20. Trivedi MK, Patil S, Tallapragada RM (2014) Atomic, crystalline and powder characteristics of treated zirconia and silica powders. J Material Sci Eng 3: 144.

21. Trivedi MK, Patil S, Tallapragada RM (2015) Effect of biofield treatment on the physical and thermal characteristics of aluminium powders. Ind Eng Manage 4: 151.

22. Shinde V, Sances F, Patil S, Spence A (2012) Impact of biofield treatment on growth and yield of lettuce and tomato. Aust J Basic Appl Sci 6: 100-105.

23. Lenssen AW (2013) Biofield and fungicide seed treatment influences on soybean productivity, seed quality and weed community. Agricultural Journal 8: $138-143$.

24. Sances F, Flora E, Patil S, Spence A, Shinde V (2013) Impact of biofield treatment on ginseng and organic blueberry yield. Agrivita J Agric Sci 35.

25. Trivedi MK, Patil S, Bhardwaj $Y$ (2008) Impact of an external energy on Staphylococcus epidermis [ATCC -13518] in relation to antibiotic susceptibility and biochemical reactions - An experimental study. J Accord Integr Med 4: 230-235.

26. Trivedi MK, Patil S (2008) Impact of an external energy on Yersinia enterocolitica [ATCC -23715$]$ in relation to antibiotic susceptibility and biochemical reactions: An experimental study. Internet J Alternat Med 6.
27. Trivedi MK, Patil S, Bhardwaj Y (2009) Impact of an external energy on Enterococcus faecalis [ATCC - 51299] in relation to antibiotic susceptibility and biochemical reactions - An experimental study. J Accord Integr Med 5: 119-130.

28. Patil S, Nayak GB, Barve SS, Tembe RP, Khan RR (2012) Impact of biofield treatment on growth and anatomical characteristics of Pogostemoncablin (Benth.). Biotechnology 11: 154-162.

29. Altekar N, Nayak G (2015) Effect of biofield treatment on plant growth and adaptation. J Environ Health Sci 1: 1-9.

30. Ertug B (2013) The Overview of the electrical properties of barium titanate. Am J Eng Res 2: 1-7.

31. Tanaka Y, Harigai T, Adachi H, Sakamoto N, Wakiya N, et al. (2013) Straindriven control of piezoelectricity in $(\mathrm{Na}, \mathrm{Bi}) \mathrm{TiO}_{3}-\mathrm{BaTiO}_{3}$ epitaxial thin films. Appl Phys Lett 102: 1-5.

32. Tanna AR, Vala K, Kushal T, Baraliya JD, Joshi HH, (2012) Synthesis of nanostructured ferroelectric tetragonal $\mathrm{BaTiO}_{3}$. J Sci.

33. Ghosh M, Dilawar N, Bandyopadhyay AK, Raychaudhuri AK (2009) Phonon dynamics of $\mathrm{Zn}(\mathrm{Mg}, \mathrm{Cd}) \mathrm{O}$ alloy nanostructures and their phase segregation. J ApplPhys 106: 1-6.

34. EL-Mallawany RA (1989) Theoretical and experimental IR spectra of binary rare earth tellurite glasses. Infrared Phys 29: 781-785.

35. Sun D, Jin X, Liu H, Zhu J, Zhu Y et al. (2007) Investigation on FTIR spectrum of barium titanate ceramics doped with alkali ions. Ferroelectrics 355: 145-148.

36. Kolodiazhnyi T, PetricA (2003) Analysis of point defects in polycrystalline $\mathrm{BaTiO}_{3}$ by electron paramagnetic resonance. J Phys Chem Solids 64: 953-960.

37. Bykov IP, Slipenyuk AM, Glinchuk MD, Morozovskaya AN, Ragulya AV (2011) Investigation of line shape of ESR spectra in $\mathrm{BaTiO}_{3}$ nanopowders. Pennsylvania State University, USA. 